DIRECT IN-VESSEL APPLICATIOIS ZXPSREOHOIS

AT HARVARD AIR CLEANIIIG LABOPATIORY

PROGKESS REPORT

For period July I, 1976 - September 30, 1976

\title{
M NTTRR
}

E. F. Mallove, W. C. Hinds, and I.. H. First

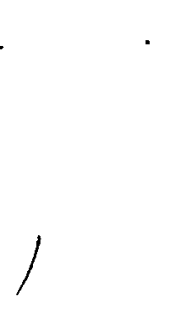

Harvard University

School of Publia Health

665 Huntington Ave.

Boston, MA 02115

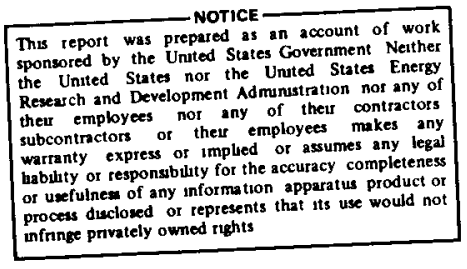

MOTICE

PORTIONS OF THIS REPORT ARE IITIGGTEEE :has beon roproducedtrom tho bect avalie: ability.

OCTOBER 1976

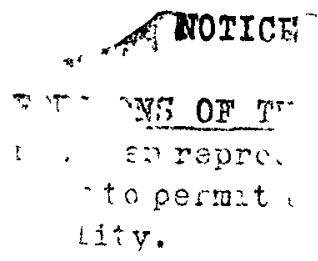

Prepared for

The U.S. Energy Research and Development Administration

Under Contract No. $E(11-1)-2801$

DOTIC:

PORTIONS OF THIS REPORT ARE ILLEGIBLE. It has been reproduced from the best avallable copy to permit the broadest possible avallability.

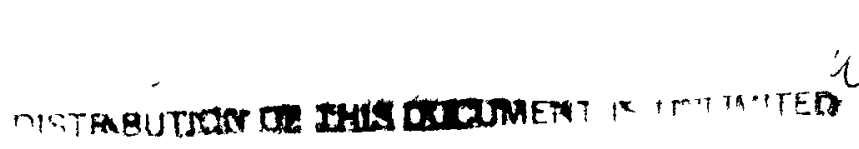




\section{DISCLAIMER}

Portions of this document may be illegible in electronic image products. Images are produced from the best available original document. 


\section{ABSTRACT}

Continuing research at Harvard Air Cleaning Laboratory on direct in-vessel emergency air cleaning systems for the LMFBR is described. The objective of these systems is to reduce the two-hour integrated dose leaking from a containment vessel by rapidly reducing the aerosol concentration within the containment. The reduction in concentration is achieved by direct action on the entire containment volume rather than by more conventional recirculating clean-up loops.

A high concentration sodium aerosol test is described in which induced turbulent agglomeration dramatically enhances sedimentation and yields a two-hour dose recuction factor (DRP) of 56 for a 4 meter hifh vessel. Attempts to achieve DRF(2-hr.) preater than 10 by increasing the powder dispersal rate in aerosol scavenging tests are also described. It was found that a combination of svstems operating simultaneously, i.e. induced turbulent arriomeration and polder scavenging, yielcied better performance than either mechantsm alone under identical sodium aerosol conditions. A DRF(2-hr.) of 20 was achieved in one test in which turbulence and powder dispersal were combined vs. ar averake $D R F(2-h r)$ of 8 for turbulent agglomeration alone and 7 for powder dispersal alone.

The construction of a pulse jet enrine and acoustic transrission duct for irradlatine a reverberant test cell with high intensity sound is described. Sound pressure levels un to $150 \mathrm{~dB}$, sufficient to agglomerate dense aerosols, vere ciemonstrated. A successful acoustic transmission method that prevented heat and exhaust rases from the iet from affecting the exoerinental aerosol is described. Plans for improvine iet pen fomance preparatory to full scaln tests with sodium asposols are discusser. 


\section{IIITRODUCIOI}

The period covered by this quarterly propress report on direct application in-vessel emertency air cleanine systems researin for the LPFBR is from July $I$, Ig76 through september 30, 1976. During, this time, further tests : ere concucted with po:der disnersal scaventinf, turbulence snirenceu a selomeration, and combinations of those approaches. A puise fet enrine and acoustic transmission duct for irradiatinf the entire $90 \mathrm{~m}$ test chamber with hifh intensity sound was constructed and successfully tested with no sodium aerosol in the chamber. A more thorough treatment of the entire test profram, including full scale acoustic ag.plomeration tests to be conducted later in 1976 , bill appear in the final program report (December 31, 1976).

\section{: II. POWDER DISPERSAL TESTS}

Further tests were performed with the promisine direct a1r cleaning mechanism of scavenglnp with dispersec poiders. Several attemnts $n$ ere made to test the effect of substantialiy increasing. the usual $1.5 \mathrm{~kg} / \mathrm{min}$ dispersal rate of crushed Iimestone. In the first test, R-27, we eliminated the uslizl1y smbloyed Acrisor. Fodel 120 dust feeder and manually dumnec 52 lis bars of crushed Iimestone in rapid succession into a funrel cinscted toward the 16" flat-plate rotary spreader. An effective dispersal rate of jo lb./min. was therby achieved. Overloainf the rotary dust spreader at this flow rate apparently cho'ed its onsrotion due to insufficient electric motor poirer, and most of the Iimestone dropped

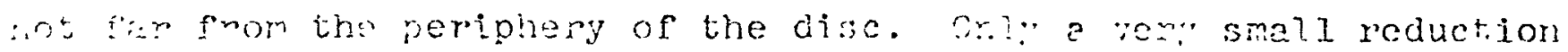

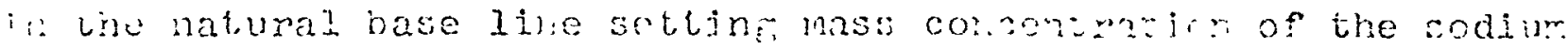

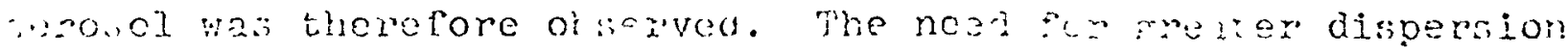

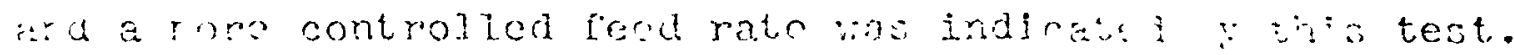


A new auger and surroundinf, feed tube was purchased for the Acrison 120 dust feeder which extends the maximum dispersal rate from $1.5 \mathrm{~kg} / \mathrm{min}$. to $15 \mathrm{~kg} / \mathrm{min}$. Test $R-37$ vas conducted vith the new auger feed at $3 \mathrm{kF} / \mathrm{min}$. With crushed limestone. The rotary spreader malfunctionad and stonped early during this test and arain the natural baseline settzine of the sodium aerosol, as determined by atomic absorotion spestrophotometry, was only slightly affected. There are pood prospeats that when uniform dispersion of crushed limestone at these higher rates is achieved, a dose reduction factor (DRP) in a two-hour period of greater than 10 could be attained readiz. The peak performance with limestone powder scavencing was previously found to be about $\operatorname{DRP}\left(2-\mathrm{hr}_{.}\right)=7$ in test R-2C. Approximately the same performance level of aerosol scavergine would be expected for a $30 \mathrm{~m}$ high vessel as for a $4 \mathrm{~m}$ vessel with the same areal mass loading of the rapid settling $200 \mathrm{un}$ scavenging particles employed. This is because the time taken for a $200 \mathrm{~km}$ barticle to settle 30 meters is less than one minute, an interval substantially less than the a hour clearance period of interest.

Commercially avallahle chilcren's playbox sand was also used in one test of powder dispersal scavenzing. During a onepound sodium fire $(R-32)$ in which a peak aerosol mass concentration of $1.54 \mathrm{gm} / \mathrm{m}^{3}$ was reached, sand was dispersed by the Acrison feeder and rotary spreader at $1.6 \mathrm{k} / \mathrm{min}$. The mass median diameter (MiD) of the sand particles by sieve analysis was found to $b=300 \mu \mathrm{m}$, whereas the MmD of crushed limestone vas $200 \mu \mathrm{m}$ A DRF(2-hr) of only 2.3 was achteved in the $R-32$ sand dispersal test, an indication of the not lnexpected decrease in the scavenping efficiency per unit mass injected fo: the larper sand renticles. A total of 150 lb. Of sand was iscorsed in the latter test. 
Table 1 summarlzes experinental conditions and data from successiul scavenging tests concilicted to date. Fror the calculated two-hour dose reduction factors it was possible to determine an "effective" particle scavenging efficiency for each test. The simple model on which the effective efficiency calculation is based, assumes that scavengin: particles are spread uniformely across the chamber. The model also assumes roinodisperse scanenging particles of size equal to the sieved particle rass median diameter (MID). Neither of these assumptions was valid in practice. Therefore, effective efflutencles above and below the true Individual particle scavenging efficiency could sosur. In this manner, effective scavenging could even exceed 1.0, as was the case during part of test $R-26$ when Ilmestone aispersion was only $0.13 \mathrm{~kg} / \mathrm{min}$. llass subsidence effects due to high concentrations of scavengers, unevon spreading by the rotor, and clumping of Iimestone (incomplete dispersion) are the responsible non-ideal effects.

Effective scavenging, effictency, $\varepsilon$, is calculated from a simple exponential attenuation model and the decay constant, $\lambda$, for exponential decline is implied by the experinentally determined $\operatorname{DRF}\left(2-h r_{0}\right)$ :

$$
\begin{aligned}
& \frac{c(t)}{c_{0}}=\operatorname{EXP}\left[-\frac{3}{2} \frac{M}{D_{s}} \frac{\varepsilon h}{D_{S} V} t\right]=e^{-\lambda t} \\
& \operatorname{DRF}(2-n r)=\frac{\lambda t}{1-e^{-\lambda i}} \text { For } t=2 \text { hrs. }
\end{aligned}
$$

Tne experimentaliy found DPl(2-hr) determises $\lambda$ ir Equation (2). use of equation (1) then gives the effar, ve eforiency ac 


$$
\varepsilon=-\frac{P_{s}}{\bar{M}} \frac{\mathrm{D}_{\mathrm{s}}}{\mathrm{H}} \lambda
$$

where $\quad \mathrm{P}_{\mathrm{S}}=$ bulk density of scavenging particles

$V=$ mass injection rate of scavenfinf particles

$\mathrm{D}_{\mathrm{S}}=$ MMD of scavenging, particles

$\mathrm{V}=$ test chamber volume

$\mathrm{h}=$ chamber height

In both test $R-25$ and $R-26$ when the fead rate of limestone was $1.5 \mathrm{~kg} / \mathrm{min}$, the determinec effective efflclencies were of the same order, 0.30 and 0.36 , respectively. If the bulk of sodium aerosol particles are 3 to $4 \mu \mathrm{m}$, as our previous data seem to indicate, the Langmuir theoretical collection efficiency for soherical $200 \mathrm{\mu m}$ scavengers lies between 0.2 and 0.35 . The lower limestone injection rate test at $0.13 \mathrm{~kg} / \mathrm{min}$. yielded an effective collection efficiency of 2.3. This efficiency was calculated by again assuming $D_{S}$ to be $200 \mu$. The fact that the efficlency is greater than 1.0 seems to incicate that much of the aerosol collection was accomplished by the scavenger fraction less than $200 \mathrm{\mu m}$. The theoretical collection efficiency of, for example, a $100 \mu \mathrm{m}$ scaverger for $3-4 \mathrm{\mu m}$ aerosol particles is st111 a fairly suostantial 0.15 to 0.30 . Perhaps the decreased mass subsidence effects at the lower dispersaz rate permits much more efficient utilization of the beod range of scavengers. The theoretical collection efflctency of 300 um sand canticles vould be betveen 0.2 and 0.4 , so the experimentaily deternined value of 0.11 seams to result from non-uniform dispersal and more of the scavenginr. burden being shifted to partiales smalier than 309 m. 
III. TURBULENT AGGLOMERATION TESTS

Two tests of enhanced turbulent agglomeration were performed under conditions not previously attempted. In test $R-38$ depleted In Figure 1, 3 lbs. of sodlum were burned and the pool f1re was augmented by blowing compressed air over the molten sodium. These conditions reslitted in a peak aerosol mass concentration of $12 \mathrm{gm} / \mathrm{m}^{3}, 40 \mathrm{minutes}$ after initiation of the fire. The $3000 \mathrm{cfm}$ recirculating blower with shroud in-place was started at $t=43 \mathrm{~min}-$ utes when the concentration was still near $12 \mathrm{gm} / \mathrm{m}^{3}$. An abrupt concentration fall-off yielded a DRF(2-hr) of 56. This experiment and turbulence tests previously conducted at high peak mass concentrations show a trend toward higher DRF's with increasing paak mass concentrations (see Table 2). Theoretical formulations of turbulent agglomeration 1 predict this behavior as well. Turbulent agglomeration methods will therefore be especially sultable for treating HCDA accidents which involve high concentration sodium aerosols, but wiIl be less effective for lower concentration eerosols stemming from smalier fires.

Turbulent agglomeration test, $R-34$, was perforned with the blower shroud exhaust pointed down toward an impaction surface within several inches of the outlet. A DRF(2-hr.) of 7.6 was achieved, a value which is in the range of DRE's obtained with the shroud pointed up or removed entirely. Since very little Impaction deposit was observed near the bloner outlet, this is a further plece of evidence that nost of the cleaning effect in these tests is in fact due to ennanced sedimentation by turbulent agglomeration rather than by centrifugal air cleaning. In the blower or impaction on the fioor. 


\section{COMBINED POWDER DISPERSAL AND MURBULENCE TESTS}

Several tests were done which combined the cleaning mechanlsms of scavengine and turbulent ageloneration. In both test $R-29$ and $R-31,1$ lb. of sodium was burned under standard conditions, afterwhich turbulence and scavenging with crushed Iimestone (MMD $=200 \mu \mathrm{m}$ ) were applied; first, successively and then, simultaneously. In R-29 the bloner was turned on for 8 minutes after a peak concentration of $1.5 \mathrm{gm} / \mathrm{m}^{3}$ had been reached. Immediately after the blower was shut down, 200 Ibs. Of Iimestone powder was dispersed at $1.5 \mathrm{~kg} / \mathrm{mIn}$. The objective was to "grow" larger target aerosol particles which would be more readily collected by the scavenging limestone particles. A DRF (2-hr.) of only 5.1 was achieved, a smaller figure than to be expected from either turbulence or powder dispersal trled separately. Turbulent agglomeration apparently reduced the mean aerosol particle size rapidy (due to greatly enhanced sedinentation), which then made powder scavenging less successful or the bulk of the remaining aerosol.

Test R-3I, on the other hand, vias drematically successful, showing that combining simultaneously turbulent agglomeration and powder dispersal scavenging coula lead to a DRF (2-hr) greater than those attainable with elther mechanism separately. Flgure 2 1llustrates the decline of suspended sodiui: mais (neasured spectrophotometricaliy from fliter samples) curing iest R-3i in which a DRF (2-hr) of 20 was attained. Ths blower was operated continuously from $t=31$ minutes, when the tosal aerosol coneentration was about $2 \mathrm{gm} / \mathrm{m}^{3}$, and $200 \mathrm{lbs}$. of erushed 11 mestone was dispersed at $1.5 \mathrm{~kg} / \mathrm{min}$. 
The increased relative motion between scavenging particles and aerosol particles produced by the turbulence along with better dispersion of dust because of turbulence most likely explains the improved DRF in this test.. Normaliy, DRF's for turbulent agglomeration and scavenging, performed separately under the sare conditions, would both be about 8 .

\section{HIGH INTENSITY ACOUSTIC FIELD GENERATION}

The potential advantages of acoustic aeslomeration for a direct-acting emrgency air cleaning system have dram increasing attention 2,3. Sonic fields exceeding sound pressure levels roughly $140 \mathrm{~dB}$ are known to produce striking rapid coagulation effects on high concentration aerosols. Most experimental data and theoretical treatments have dealt with staning sound waves in specially tuned columns. Direct application of sonic agglomeration to a large, irregularly shaped contalnment vessel atmosphere could not be achieved conveniently with standing waves. It is more appropriate to envision a high intensity reverberant acoustic field throughout the vessel. Such a fiezd could be produced by an high intensity sound source such as sirens, pulse jets, or whistles. Non-standing wave flelds, or progressive acoustic waves, are from theoretical considerations thought to "sirep" the aerosol particle size distribution and bring about other kinetic motion and coagulation between a broad range of size classes. 
Following the novel experimental approach of David Scott 4 at the Univerlsty of Toronto in Canada, we selected pulse jet engines as convenient and efficient high intensiti sound generators. A special test geometry vas reauired to irradiate the test chamber volume with high intensity sound and not to simultaneously disturb the aerosol with laree scale turbulence, heating, and chemical interference from the jet exhaust. The latter factors would make it impossible to ssparate the soughtafter affects of sonic agglomeration from interference effects. Figure 3 illustrates the experimental arsangement in which a U-shaped duct commuting with the atmosphere external to the chamber encloses the pulse jet engine. Gasoline, compressed alr, and a high voltage spark for starting the jet are fed to the engine by narrow gauge rubber tubes and wire. The crucial sound transisision element is the $2 \mathrm{ft}$. Lon; by 8" dlameter tube of $2 \mathrm{mll}$ thlck stainless steel foil which surrounds the engine. The Dyna Jet "Red Head" pulse jes encine* that was employed produces a $240 \mathrm{~Hz}$ finite anplitude wave train which, due to the assoclated 1.5 meter wave length, penetrates the flexible foil membrane with little alternation.

A lengthly series of tests was required to oparate the pulse jet at high sound levels. The jet reguires a very lean gasoline-alr mixture to yleld high sound leyels, but such operation, when prolonged, leads to component fallure sesause of the high combustion temperature.

With the foil transmission membrane removed, sound pressure levels up to 148 aB were recorded with a B+K instruments sound meter operating in the fllat response.

"Curtis Dyna - Products Corporation, lestîla, Indiana, 46074 . 
The concept of a metal foll acoustic transission membrane was proved feasible durlne the short operating tirie (several minutes) before either the combustion inlet flapper valves or combustion chamber itself falied under heat stress. The foll transmitted sound adequately and did not overheat or tear. Measuring the sound level in the chamber dusing operation with the foil in place gave sound levels roughily only $10 \mathrm{~dB}$ less than with the foll off. Hoifever, only a less reliable sound meter was avaliable for the foil in-place test so the measurement is uncertain. It is possible that much less than a $10 \mathrm{~dB}$ reduction occurred.

It became apparent that a more reliable puzse jet engine would be required to allow prolonfed exposure of the aerosol to high intensity sound. An englne of more heat resistant construction which operates with "aerodynamic" valves rather than mechanical valves has been special-orcered from the metallurgy section of the Ontario Research Foundation near Toronto, Canada. This pulse $f e t$, which proved itself in other sonic agelomeration tests 4, uses propane for fuel rather than gasoline. When the engine is recelved it vill be interfaced With the existing acoustic test set-up and :ill be operated with a sodium fire in the chamber. 


\section{REFERENCES}

1. Beal, Stuart K., "Turbulent Agglomeration of Suspensions", Journal of Aerosol Science, Vol. 3, 1972, 113-125

2. H1Il1ard, R.K., McComack, J.D., and Postma, A.K., "Evaluation of Alr Cleaning System Concepts for Emersency Use in LMFBR Plants", Hanford Englneering Development Laboratory Report TC-536, (December 22, 1975).

3. Scott, D.S. (editor), "Research Interest-Activities Summaries on Acoustic-Aerosol Interactions", from a technical discussion session held during the 82nd National lieeting of the American Institute of Chemical Engineers, Atlantic C1ty, ii.J., August 30 - September 1, 1976.

4. Scott, D.S., "A New Approach to the Acoussic Conditioning of Industrial Aerosol Emissions", Journal of Sound and Vibration, Vol. 43, No. 4, 1975, 607-619. 
TABLE I

POWDER DISPERSAL TEST CONDITIONS AND SCAVENGING EFFICIENCY

Test if

$R:-25$

$R-25 A$

$R-263$

$?-32$
Scavenging Particles

Limestone, $200 \mu \mathrm{m}$ MMD

Limestone, 200 um MMD

Limestone, $200 \mu \mathrm{m}$ MMD

Sard, $300 \mu \mathrm{m}$ MMD
Dispersal Rate $\quad \underline{\operatorname{DRF}(2-h r)}$

$1.5 \mathrm{~kg} / \mathrm{min}$

$0.13 \mathrm{~kg} / \mathrm{min}$.

$1.5 \mathrm{~kg} / \mathrm{min}$.

$1.6 \mathrm{~kg} / \mathrm{min}$.
6.0

4.1

7.2

$2 \cdot 3$
Effective Scavenging Erficiency

0.30

$2 \cdot 3$

0.36

0.11 


\section{TABLE ?}

EFFECTIVENESS OF TURBULENT AGGLONERATION IITH RESPECT TO

\section{SODIUM AEROSOL PEAK MASS CONCEIMPATION}

Test \#'s

$14 ; 15,16,18,19,34$

$20,21,22$

38
Peak Mass Concentration $\left(G M / M^{3}\right)$

$1.2-2.3$

$3.6-4.6$

12
$\operatorname{DRF}(2-h r)$

$4.2-8.2$

$25-40$

56 


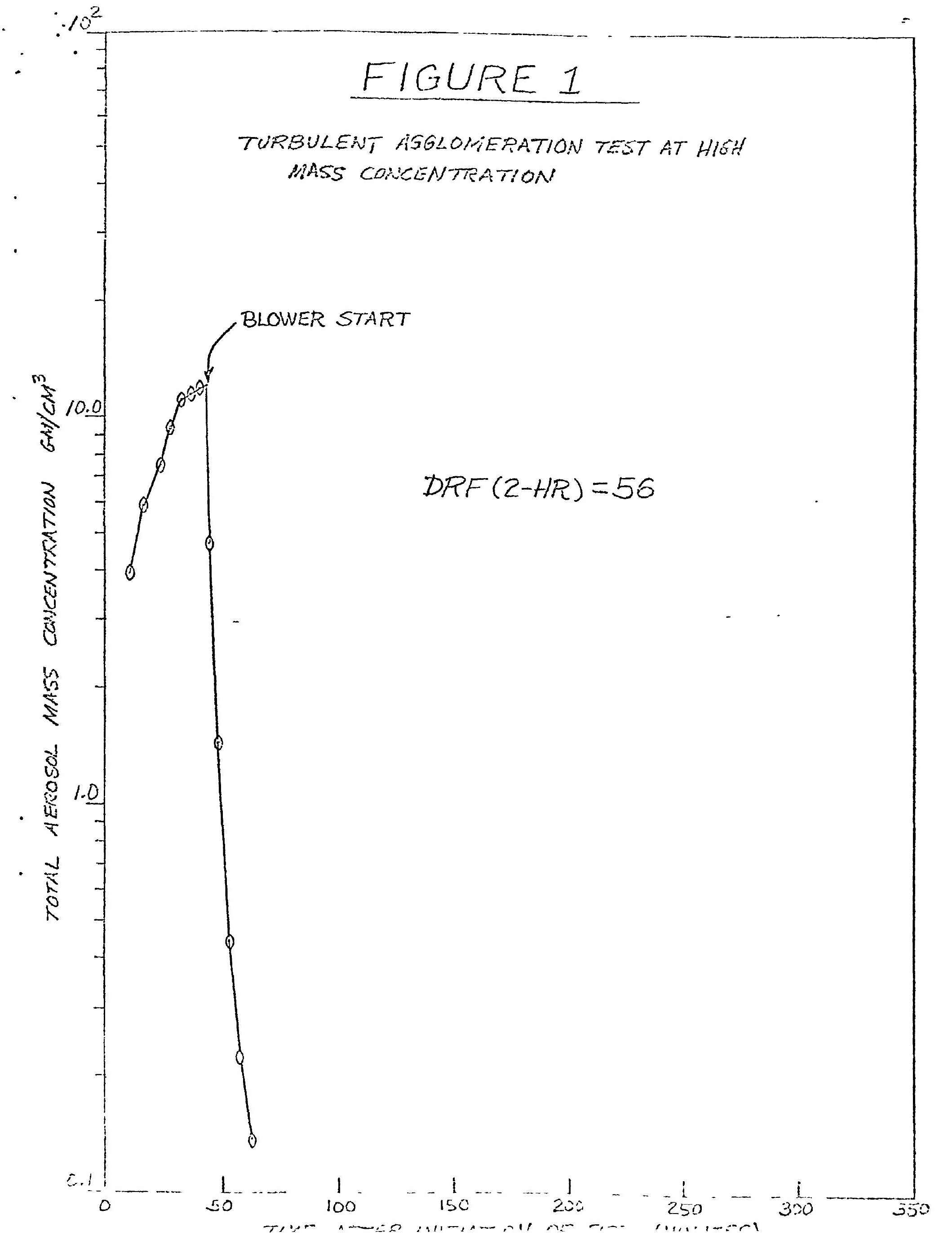




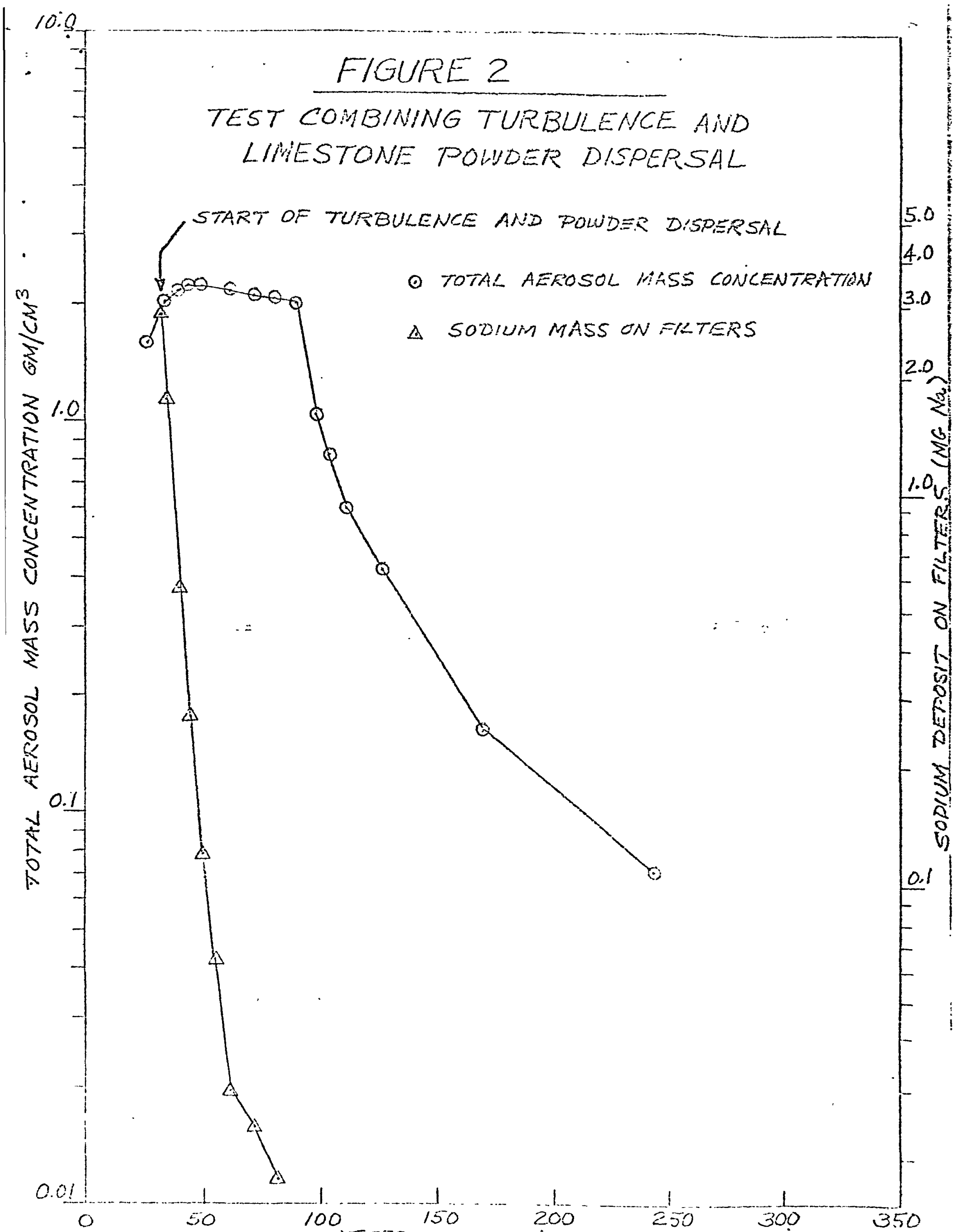


FIGURE 3

ACOUSTIC AGGLOMERATION TEST CONFIGURATION
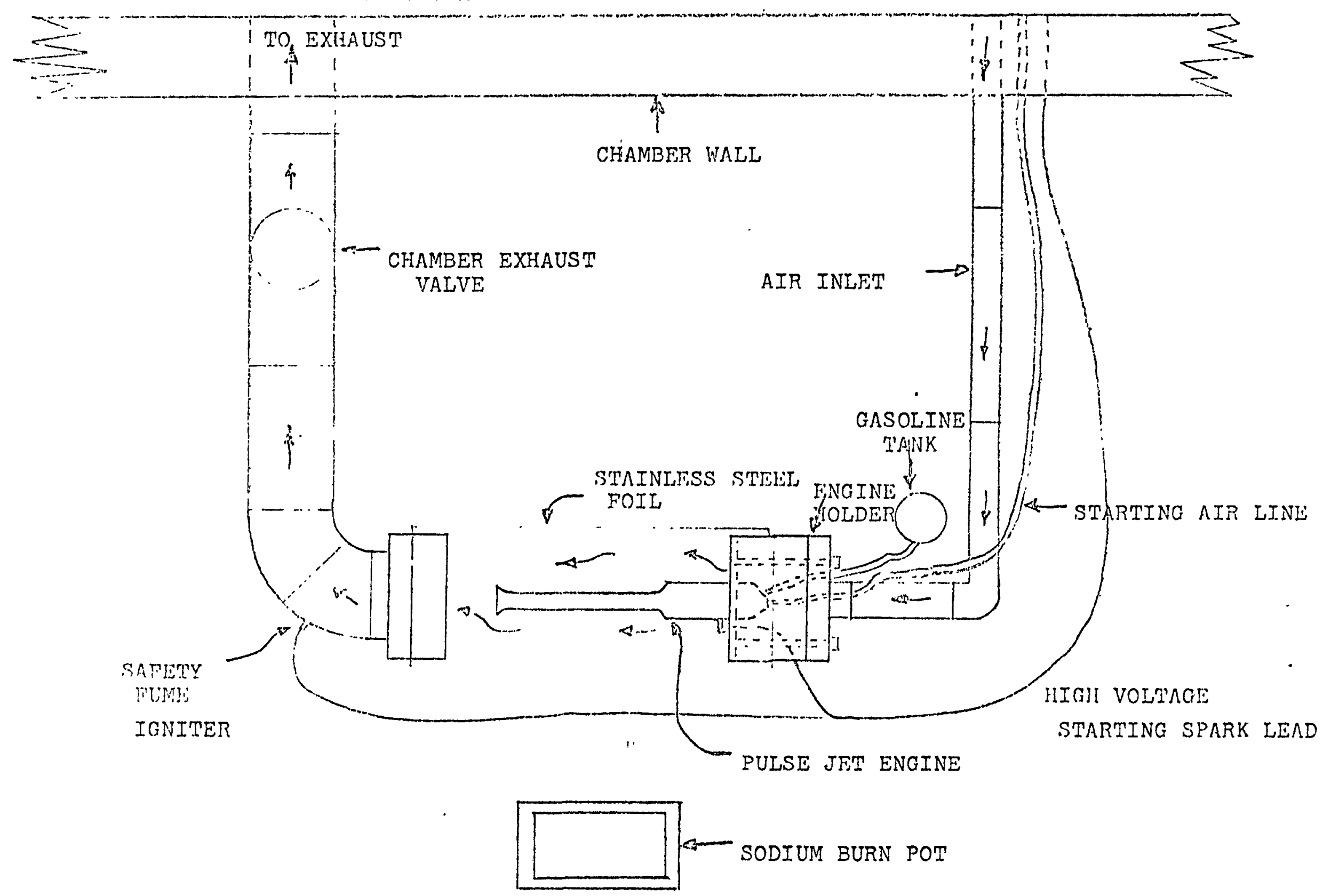


\section{FIGURE 4}

DYNA JET "RED HEAD" PUISE JET ENGINE

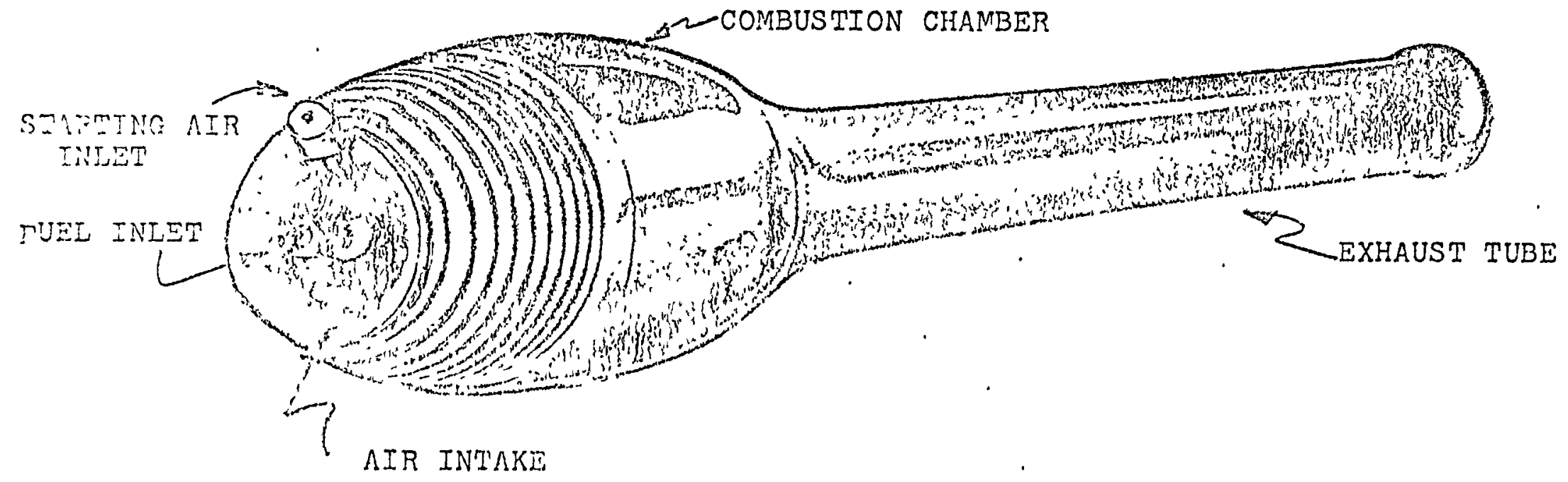


Financial Staterent of Esiriater Costs

Special Research Sunport ifreerent

Ilarvard Universit:-

Contract No. E(11-1)-2801

For the Period September I, 1975 through January 1, 1977

1. Estimated Total Project Costs for the Clirment Period $\$ 88,221$

2. Total Amount Chargeable to ERD (Approvea Surport Percentage $=100 \%$ of Item 1 )

$\$ 88,221$

3. Cumulative Support Costs

$\$$

0

4. Estimated Total Cumrnulative Support Costs

$\$ 88,221$

5. Cumulative support Ceiling

$\$ 88,221$

6. Anticipated Difference Between the Estir:三ted Total

Cumulative Support Josts and the Cumulative Support Ceiling 